${ }^{\mathrm{I}}$ Universidade de São Paulo (USP),

Departamento de Sociologia, São Paulo, SP, Brasil

fraya@usp.br

Fraya Frehse'

\title{
DA DESIGUALDADE SOCIAL NOS ESPAÇOS PÚBLICOS CENTRAIS BRASILEIROS ${ }^{1}$
}

Imagine-se o leitor caminhando, no horário comercial de um dia útil qualquer, em busca da praça simbolicamente mais central da maior megacidade brasileira da atualidade. Entre as 9 e as I 9 horas de segunda a sexta-feira, invariavelmente lhe indicarão a Praça da Sé. Ali se verá circundado por edifícios cuja monumentalidade arquitetônica simboliza o poder de instituições religiosas, político-administrativas e jurídicas historicamente centrais em São Paulo. Já sob os pés terá ou o tablado de pedra que faceia a Catedral Metropolitana ou a ampla área ajardinada que o ladeia com espelhos d'água, cascatas, canteiros e esculturas implantados acima do principal entroncamento metroviário da cidade. Monumentos e tablado sintetizam o cenário físico dessa que é a praça-sede da primeira catedral católica paulistana, hoje em dia a metrópole econômica e politicamente mais influente do país

Porém há bem mais que pedra, ali e então. O leitor se deparará com os pedestres multifacetados que pontilham o cenário físico em meio às multicores de mercadorias variadas, de pregões e pregações, passos e prosas. Há, de um lado, transeuntes, isto é, homens, mulheres e crianças que se particularizam por passar fisicamente com regularidade por ali (ver Figura I).

É o caso do próprio leitor, em circulação imaginária por ali. Tipo urbano historicamente próprio da chamada cidade moderna que a literatura e a sociologia europeias oitocentistas e das primeiras décadas do século XX eternizaram no dandy, no flâneur e no blasé, o transeunte convive com um tipo de 
pedestre que se distingue do primeiro justamente por não transitar por ali - daí a denominação não-transeunte, que venho utilizando para fins analíticos (Frehse, 2013a, 2013b, 2013c) (ver Figuras 2, 3 e 4).

São engraxates e pregadores, vendedores ambulantes, músicos e os frequentemente autodenominados moradores de rua. Sobretudo homens, mas às vezes também mulheres, muitos são aposentados ou desempregados que ali se deixam ficar fisicamente com regularidade, de pé, sentados ou mesmo deitados na escadaria da catedral, numa mureta, quando não no próprio chão (ver Figura 5).

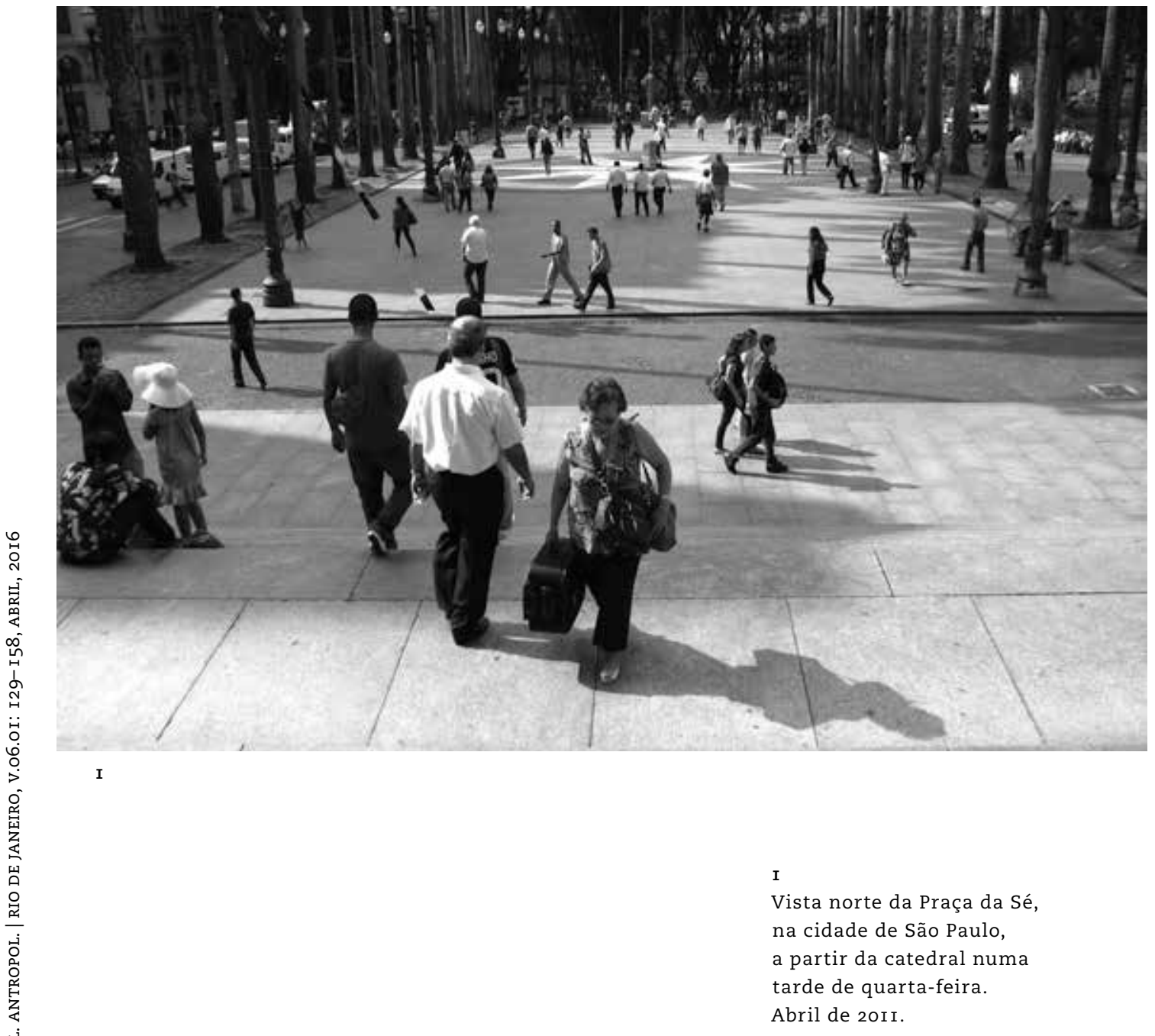




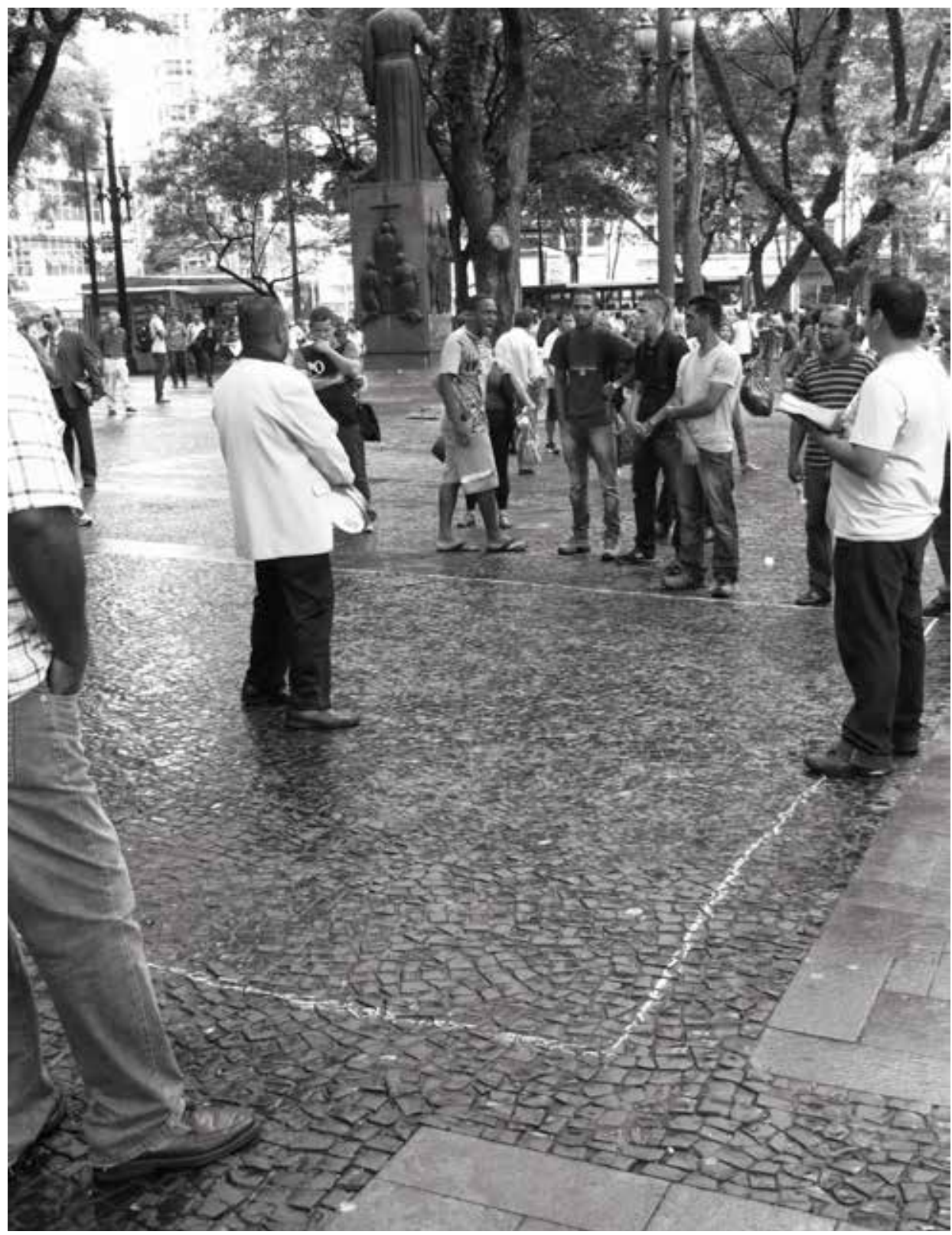

Pregadores e seu público um pouco mais ao sul do mesmo setor sombreado, numa tarde de segunda-feira.

Fevereiro de 2012. 


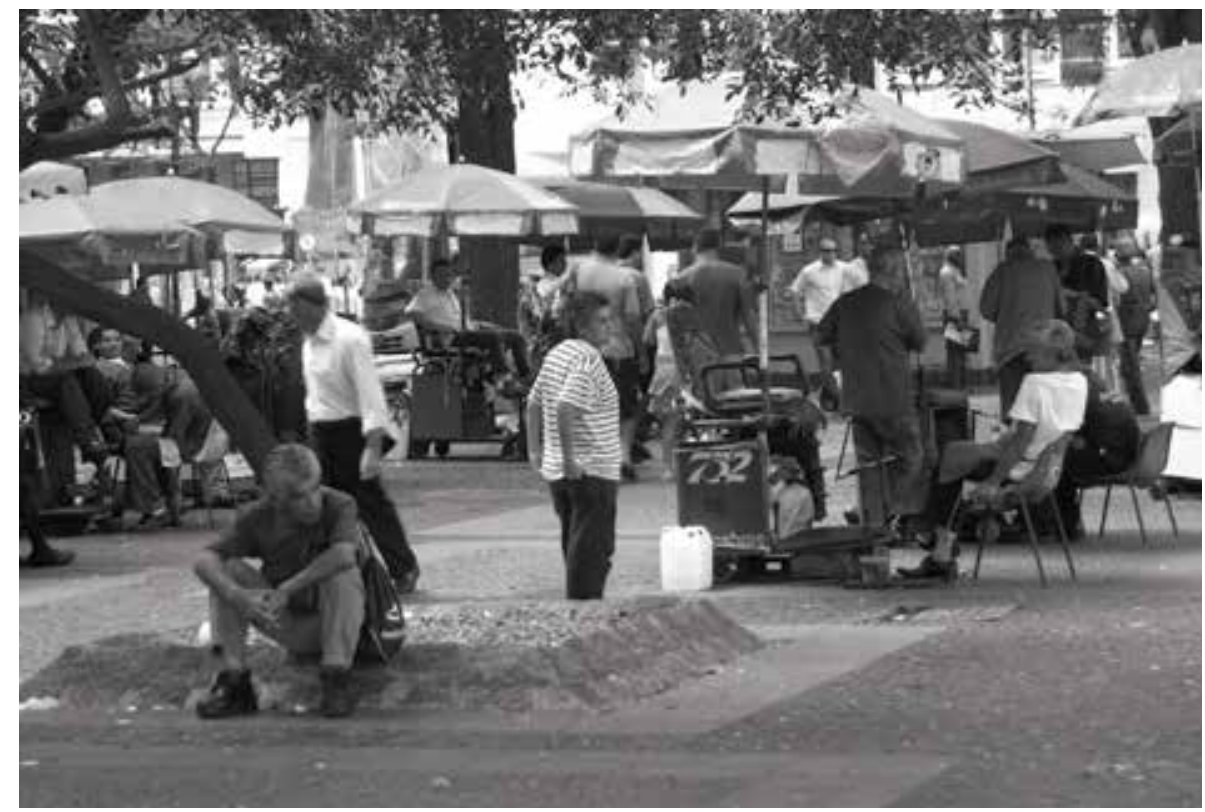

4 


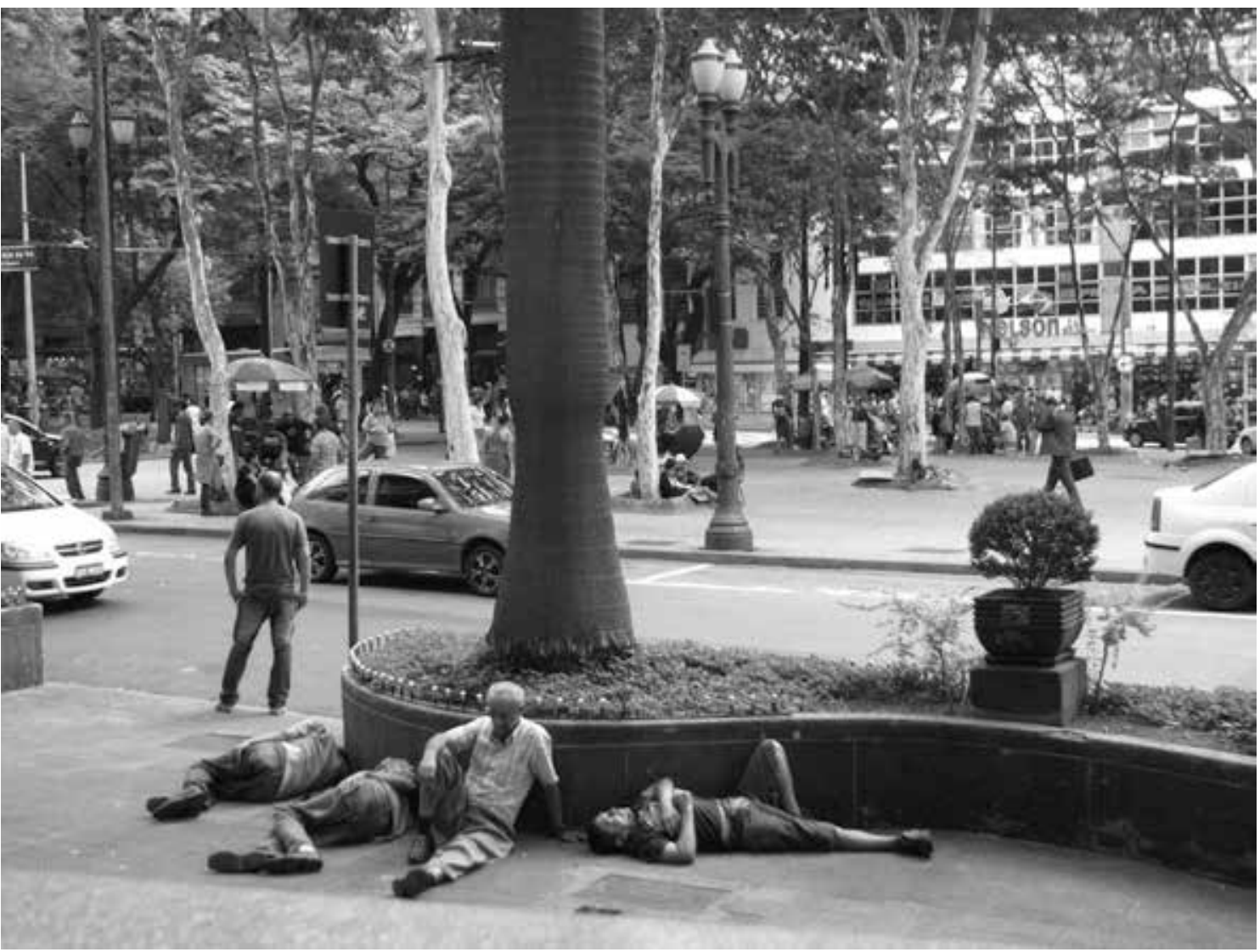

3

Na mesma tarde de segundafeira da figura 2, vista norte do setor sombreado do tablado. Fevereiro de 2012.

4

Músicos e seu público um pouco mais a nordeste do setor sombreado do tablado numa tarde de sexta-feira anterior à figura 3.

Abril de 20II.

5

Vista oeste em direção ao setor triangular do extremo norte da praça na mesma tarde de quarta-feira da figura I. Abril de 20II. 
Interessa aqui a coexistência física desses dois tipos urbanos nesse espaço, no tempo específico do horário comercial dos dias úteis. O objetivo é contribuir para o tema das relações entre desigualdade social e espaço urbano no Brasil, tal como o rastreei em pesquisa bibliográfica recente. ${ }^{2}$ Recorrendo a conceituações sociológicas, antropológicas e da ciência política, autores com formações acadêmicas diversas enfrentam o assunto desde os anos I970. ${ }^{3} \mathrm{E}$ apontam para o papel da distribuição residencial dos grupos sociais no espaço urbano sobre a produção e/ou reprodução das assimetrias de posicionamento social ali, com a aceleração da globalização econômica, que alocam na década de I990. Porém, e espaços tão absolutamente receptivos à diversidade social urbana quanto as praças que sediam as catedrais dos centros históricos metropolitanos do Brasil em momentos "comerciais e úteis"?

Quanto ao espaço urbano, acepções de "público" correntes na bibliografia internacional atual remetem ao mais amplo acesso: de um lado, acesso a informações sobre os indivíduos ali; de outro, acesso por indivíduos conformes a padrões de conduta de expectativa bem geral (Harding \& Blokland, 20I4: I87-88). Ora, a dinâmica social que agita a Praça da Sé paulistana nos intervalos temporais em questão potencializa de modo notável a abrangência dos dois tipos de acesso. A coexistência física intensa de transeuntes e não-transeuntes sinaliza para um espaço público que, ao menos no período comercial, é epicentro da "simultaneidade", do "encontro" das diferenças, possibilidade histórica que particulariza a cidade como espaço produzido socialmente - com todas as contradições aí implícitas, e que dificultam justamente a convivência das diferenças (Lefebvre, 2009: 86). Passado o horário comercial, comércio e repartições baixam as portas, e as praças viram territórios, sobretudo de alguns grupos: não raro espaços residenciais de moradores de rua, ou dos ócios e negócios de comerciantes e consumidores de drogas mais ou menos ilícitas.

À luz dessas ponderações, meu objetivo específico é enfrentar, por referência empírica precisamente à praça-sede da catedral paulistana desta segunda década de século XXI, uma questão teórica que atravessa o debate sobre o estatuto explicativo do espaço na produção e/ou reprodução (dependendo da perspectiva metodológica) das assimetrias de posicionamento social nas metrópoles brasileiras num contexto de globalização econômica que se agudiza de modo sui generis a partir dos anos i990. Como e por que a produção dos espaços públicos centrais de tais cidades interfere nas transformações e/ou continuidades da desigualdade? Com base em particular na Praça da Sé, que etnografei às segundas e sextas-feiras comerciais e úteis de 2013, importa o modo como e as razões pelas quais o uso que os pedestres fizeram corporalmente dali então incide sobre a (re)produção da desigualdade social na São Paulo atual.4

A perspectiva metodológica é específica, por referência àquelas que impregnam a bibliografia investigada. Inspira-se na convergência entre orienta- 
ções dialéticas e fenomenológicas acerca lugar do conhecimento de senso comum na vida cotidiana e na História (Martins, 2008a: 53). Dialoga, de um lado, com o método dialético com que Henri Lefebvre apreendeu sociologicamente "a produção do espaço" nos anos I970. Assumo como pressuposto que "cada corpo vivente é um espaço e tem seu espaço: ele ali se produz e o produz" (Lefebvre, 2000: I99, grifos no original). Assim, é pela mediação do corpo que os “'sujeitos' membros de grupos sociais" percebem sensorialmente o espaço (através dos membros, órgãos sensoriais, gestos) e o vivem simbolicamente (via imagens e símbolos), em meio ao vigor das concepções racionais (de cunho científico-ideológico, no capitalismo do século XX) que o impregnam (Lefebvre, 2000: 48-9). Por considerar, ademais, que o espaço (social) é um produto social que ao mesmo tempo interfere na prática social ("as relações sociais só têm existência real no e pelo espaço" - Lefebvre, 200o: 465), sensibilizo-me para a possibilidade de que seja, entre outros, através daquilo que chamo de uso corporal de espaços como as praças da Sé brasileiras no período comercial, que as grandes cidades atuais do país são produzidas como socialmente desiguais.

Como essa perspectiva acarreta buscar as regularidades simbólicas de conduta corporal na interação social, tema inexplorado por Lefebvre, recorro, de outro lado, à fenomenologia de Erving Goffman (1963: 33-4, I7) sobre o "idioma corporal" dos indivíduos nas situações de copresença física com terceiros; isto é, o discurso convencional e normatizado prenhe de signos relativos tanto à aparência física quanto a "atos pessoais" como vestimenta, porte, movimento e posição, gestos, posturas, ornamentos faciais e expressão emocional dos indivíduos, nos ambientes espaciais onde ocorre a interação social

Quanto à questão do como, espero evidenciar o quanto a perpetuação da desigualdade social em São Paulo também deve a duas formas de desigualdade à primeira vista insignificantes, pois (re)produzidas na vida cotidiana dos pedestres num lugar fisicamente tão circunscrito como a Praça da Sé. São assimetrias de posicionamento social implícitas, de um lado, nos padrões de comportamento corporal e, de outro, nas classificações morais dos pedestres do logradouro. Já o porquê dessas disparidades reside na densidade histórica profunda das regras de conduta implícitas no uso corporal de ruas e praças centrais paulistanas: elas se vinculam historicamente aos primórdios da São Paulo pós-escravista.

\section{ESPAÇOS E RAZÕES DAS DESIGUALDADES NAS CIDADES BRASILEIRAS DAS CIÊNCIAS SOCIAIS}

A preocupação com o papel do espaço na perpetuação da desigualdade social nas grandes cidades se confunde com os primórdios da própria sociologia. Basta relembrar a vívida descrição que Friedrich Engels (1972: 276, I86) fez da distribuição social das moradias na Manchester da década de I840, atribuindo 
a origem da penúria do operariado à indústria. Isso, sem mencionar a conceituação pioneira de Robert Park (I925: Io, 2, 43) sobre o protagonismo da "segregação populacional”, afora meios de transporte e de comunicação, no estabelecimento de distâncias de natureza não apenas física, mas "sentimental" entre as coletividades humanas, nesse "habitat natural do homem civilizado" que seria a cidade, embora a "segregação do pobre, do viciado, do criminoso e das pessoas excepcionais em geral" tivesse uma "importância especial" em tais distâncias.

Ambas as referências evidenciam contrapontisticamente ao menos uma especificidade epistemológica do debate sobre as cidades brasileiras dos anos I 990 em diante. Os pesquisadores questionam explicitamente a interferência do espaço na produção e/ou reprodução das assimetrias de posicionamento social ali..$^{5}$

Decerto esta tendência não nasce na academia brasileira, ou no final do século XX. Um marco historicamente inaugural é a reflexão lefebvriana sobre o papel mediador de tempo e espaço na (re)produção da vida cotidiana no mundo moderno, particularmente na cidade - até que o espaço, ou melhor, sua produção, merecesse destaque (ver, por exemplo Lefebvre, I958, 2000, 200Ia). ${ }^{6}$

Instigante é que as respostas recentes no Brasil fogem a qualquer determinismo espacial, crença numa suposta causalidade direta entre características do espaço físico e aquelas da vida social. Embora apenas raramente explicitem as concepções de espaço com que trabalham,7 as abordagens sugerem autores sensíveis à dimensão social do espaço; ou seja, a sua natureza socialmente construída/produzida (dependendo do marco teórico), em conformidade com as principais conceituações das ciências sociais acerca do espaço (Frehse, 20I3d). Uma evidência é o enfoque comum em estruturas e processos sociais relativos à distribuição física de grupos sociais no espaço urbano.

Chego assim ao cerne da discussão sobre como e por que o espaço interfere na (re)produção da desigualdade social nas cidades brasileiras dos últimos 25 anos. Dada a extensão da bibliografia, operacionalizo a dupla questão teórica em três perguntas específicas que, logicamente articuláveis, permitem ordenar de modo sintético o debate: quais as principais formas de desigualdade social que animam a discussão, e, respectivamente, suas expressões espaciais e razões (causas, determinações, dependendo da orientação teórica)?

Quanto às formas, a bibliografia associa o fenômeno ao acesso assimétrico a bens materiais e/ou bens imateriais socialmente valorizados. Dentre os primeiros, o destaque cabe à terra, à propriedade (por exemplo, Rolnik, I999; Ribeiro, 200I/2002; Lago, 200I/2002; Martins, 2008b, 20I I), mas também a renda, moradia, serviços ou infraestrutura urbanos (Lago, 200I/2002: I56s). Já o elenco de bens imateriais é mais abrangente, anunciando-se tanto em alusões a disparidades de oportunidades de inclusão das pessoas nos processos eco- 
nômicos (Martins, I997: 20s; Raichelis, 2006: I6) quanto em referências às "condições de vida" em espaços diversos da cidade, e ao "empoderamento" dos respectivos grupos sociais ali (Kowarick, 2000: 8I; Ribeiro, 2001/2002: 80). Há quem remeta ainda a políticas públicas, mercado de trabalho e contato entre grupos sociais variados (Marques, 20005: 42). ${ }^{8}$

Daí que os protagonistas de todas essas desigualdades sejam "pobres", "camadas populares", "comunidades de baixa renda", tipos não raro contrapostos a "ricos", "classes médias", "elites". 9 São categorias que acentuam a dimensão material da desigualdade social, embora não falte quem já há tempos saliente as privações imateriais que a pobreza oculta. ${ }^{\text {Io }}$

Sem desmerecer essas sutilezas analíticas todas, importa que elas apontam para uma forma definida de desigualdade social: aquela referente ao acesso a bens materiais e, sobretudo, imateriais que as cidades brasileiras viabilizam para grupos sociais que residem em determinados espaços. Tal modalidade de assimetria se distancia significativamente das formas que, adiante, os padrões de uso corporal da Praça da Sé paulistana evidenciarão. Mas ela me aproxima da questão de como tais desigualdades se expressam espacialmente.

Alguns autores referenciam notadamente desigualdades "socioespaciais" (Ribeiro, 200ob, 2002), fazendo par com os incontáveis estudos que associam a constituição e/ou perpetuação das desigualdades de acesso a periferias, favelas e/ou cortiços. Já quando o assunto são as lógicas de distribuição espacial de grupos sociais nas cidades, o investimento investigativo tem se dirigido, de um lado, aos padrões de localização residencial e, de outro, à segregação, sua variante autossegregação ou à chamada gentrificação. Enfim, proliferam reflexões sobre a vinculação de todos esses fenômenos à desigualdade social e/ou à pobreza - muitas vezes com base em variações controversas da própria noção de pobreza. ${ }^{\text {II }}$

Se são diversas as vertentes interpretativas relacionadas a tais temas - e seus vínculos (ver, entre outros, Marques, 2005: 33-5, 38-44) -, tais diferenças se relativizam bastante sob o ângulo do uso corporal de espaços públicos centrais como praças da Sé. Elas inserem-se num amplo senso comum acadêmico sobre o papel dos usos habitacionais do espaço na produção e/ou reprodução de desigualdades de acesso no Brasil urbano dos últimos 25 anos.

Associo usos do espaço a comportamentos corporais, formas de sociabilidade ou à conjunção padronizada de ambos em atividades sociais como comerciar, mendigar, jogar, morar etc. ali (Frehse, 2009: I53-54). Já o habitar refere-se ao "fato antropológico" de os seres humanos se fixarem no solo, se enraizarem, ali viverem de modo regular (Lefebvre, 200Ib: 9-I2); um fenômeno prenhe de coerência e conflito - e história. O habitar constitui-se de bens móveis e imóveis, produtos da atividade prática humana; e os modos de habitar se exprimem na linguagem ou "objetivamente", isto é, em conjuntos de 
obras, produtos, coisas constituintes de um "sistema parcial: a casa, a cidade, a conurbação".

Ora, não é essa a atividade social implícita na variedade de estudos que tematizam a desigualdade social nas cidades brasileiras referenciando tipos de moradia, a visão de mundo e os modos de vida (doméstica) dos respectivos moradores; a estrutura socioespacial das localizações residenciais ali; enfim, características e redes sociais em vizinhanças pobres? Como privilegio o uso corporal de espaços públicos, é inevitável perguntar se outros usos e espaços de análise não ofereceriam interpretações outras sobre as formas e razões de (re)produção da desigualdade. A bibliografia comprova os vínculos entre (autos)segregação residencial, desigualdade social e pobreza urbana. Porém se habitar é incontornável, "[a] moradia é um lugar aberto" à invenção e à descoberta (Lefebvre, 200Ib: Io). A vida humana ali envolve, pois, também outros usos e espaços.

Mas quais usos, nas ruas e praças brasileiras das ciências sociais? Prevalecem associações a determinadas atividades sociais (Frehse, 2013C: I02-5). A bibliografia tematiza sobretudo os conflitos mais ou menos cotidianos implícitos no trabalho informal, na moradia, na atuação de movimentos sociais e/ou no deslocamento pelas vias e logradouros públicos das metrópoles, e que muito devem a disparidades de posicionamento social. No entanto, faltam reflexões específicas sobre o problema aqui em foco - mesmo quando a dimensão corporal dos usos das ruas e praças é contemplada (Frangella, 20 I I; Rui, 20 I5). ${ }^{\text {I2 }}$

Desse modo, desemboco na questão dos porquês de a desigualdade social no espaço urbano brasileiro se (re)produzir semeando periferias e centros históricos peculiares, favelas, condomínios fechados e cortiços, afora (autos) segregação e gentrificação. Há quem, como eu aqui, privilegie em suas respostas processos históricos de longa duração (Martins, I997: 20; 200I: 78; 2002: 9-II). Porém mais usual, quando o assunto é história, é assumir como rupturas em relação ao passado os processos econômicos e políticos do fim do século XX: a globalização econômica e a reestruturação produtiva (Ribeiro, 200ob: 68; Bógus \& Taschner, 2000: 248); o chamado modelo neoliberal (Raichelis, 2006: I9).

Já uma segunda vertente interpretativa associa a globalização à atuação de sujeitos específicos, ao articular desigualdades de acesso à segregação contemporânea: grupos sociais de maior renda monetária, o poder público e o mercado imobiliário (Ribeiro, 200I/2002: I; Lago, 200I/2002: I 57). E um terceiro tipo de abordagem atribui a perpetuação da desigualdade social no espaço urbano à atuação de determinados sujeitos: agentes do Estado e grupos envolvidos com a produção imobiliária, de infraestrutura e serviços urbanos (Marques \& Torres, 2005; Marques, 20I0, 20I5). Não obstante, há quem ressalte processos socioespaciais que, ligados à urbanização "arriscada", se pautariam na atuação de empreendedores privados sob o abrigo da legislação urbana (Rolnik, I999: 2-3).

Sob essa variedade de linhas conceituais percebo enfoques centrados sobretudo nas estruturas e processos sociais subjacentes aos usos habitacio- 
nais de espaços geográficos definidos dessas urbes. A forma privilegiada de desigualdade daí resultante é o acesso a bens materiais e imateriais coletivos na cidade.

Já quando os usos que importam impregnam o espaço dos corpos dos pedestres no espaço público das praças da Sé brasileiras, é de uso corporal desses logradouros que cabe aqui falar. E de assimetrias ausentes do debate, com determinações inusitadas, de longa duração.

\section{OS CORPOS SECULARMENTE DESIGUAIS DA PRAÇA DA SÉ PAULISTANA}

É hora de outro passeio imaginário. O pretexto são anotações de meu caderno de campo relativas ao trabalho investigativo que realizei, durante as tardes (I4-I8h) de 39 segundas e sextas-feiras úteis de 20I3, no amplo segmento cimentado da Praça da Sé que, cortado perpendicularmente por uma estreita rua agitada por ônibus, se abre na direção nordeste, diante da catedral. Visualmente estimo a área desse polígono em menos de um terço dos $37.500 \mathrm{~m}^{2}$ que o logradouro soma desde a radical intervenção urbanística dos anos I 970 (Milanesi, 2002: I6I). O subsolo da praça tornou-se então o principal entroncamento metroviário da metrópole, e o solo recebeu, a leste do perímetro em foco, extenso jardim delimitado por muretas. Em busca dos usos mais recorrentes do tablado cimentado pelos pedestres, concentrei-me etnograficamente tanto no retângulo pontilhado por palmeiras imperiais que faceia a escadaria da catedral (fig. I), quanto no setor retangular sombreado mais a nordeste (figs. 2-4), e no triângulo do extremo norte da praça (fig. 5).

Constatei assim que, enquanto determinados tipos de pedestres tendiam a se deixar ficar fisicamente em "espaços-tempos locais" específicos do logradouro - portanto em determinados lugares, a que corresponde uma prática espacial (Lefebvre, 2000: 2I) -, muitos outros se espalhavam por todo o perímetro. Não-transeuntes como engraxates e sapateiros, músicos de rua e pregadores pentecostais, vendedores ambulantes de cigarros e plaqueiros se concentravam nos dois setores sombreados da praça, ao menos nos dias etnografados. Dentre os moradores de rua, por sua vez, gente que permanecia com regularidade em torno de alguma árvore, estátua ou encostada a uma mureta coexistia com os muitos outros que iam e vinham, ao sabor da sociabilidade ou de alguma ocasião de trabalho, esmola ou "doação". Já entre os milhares de transeuntes, a regra era circular: e a praça toda era seu lugar.

É justamente nessas diferenças que se insinua uma primeira forma de desigualdade social que pude flagrar no logradouro. Refiro-me à desigualdade comportamental-corporal. O que chamo de comportamento corporal diz respeito a sequências de "ritmos" lefebvrianos relativas a como os indivíduos mobilizam gestos e posturas de seu idioma corporal como "técnicas corporais" no 
sentido pioneiro aventado por Mauss (Frehse, 20I I: 46); contudo, particularmente para se deslocarem nos espaços públicos.

A observação direta e as conversas informais evidenciaram sobejamente que quem se deixava ficar fisicamente com regularidade no logradouro tinha um dia a dia pautado por ao menos algumas das privações associáveis à pobreza (Martins, I997: I8). A praça era alvissareira, de um lado, pela falta prévia de emprego fixo: eram muitos os transeuntes de passagem que encomendavam consertos ou polimentos de sapatos; compravam DVDs de pregação ou de música; davam esmolas. De outro lado, permanecer ali com regularidade possibilitava contornar carências de alimentação, saúde e moradia - seja graças às ONGs que semanalmente distribuíam comida e roupa, às assistentes sociais da Prefeitura que "monitoravam" periodicamente o estado de saúde dos moradores de rua e se empenhavam por vagas em albergues, seja, enfim, pelos transeuntes que "compravam um lanche". Do ângulo dessas privações, importa pouco que a praça se situe num perímetro ao qual decerto não se aplica o "tipo de desigualdade espacial" de bairros periféricos paulistanos: "as desigualdades de acesso" - ao mercado de trabalho, às políticas públicas (Marques, 2005: 42).

Quando se considera que o comportamento corporal da permanência física regular no logradouro vem acompanhado de atributos outros do idioma corporal que conotam privação ao menos material, é tentadora a impressão de que os não-transeuntes da Praça da Sé de 2013 se posicionam socialmente na base da pirâmide social paulistana atual. Proliferam em meu caderno de campo alusões a calças e camisas curtas ou longas demais, e puídas; casacos ou mantas surrados, por vezes furados, para o frio do relento; sacolas plásticas e carrinhos de supermercado para o transporte de objetos pessoais, na falta de bolsas, mochilas, um armário, um abrigo fixo. Ademais, não raro me deparei com mãos e rostos enegrecidos pela fuligem do trânsito de carros e ônibus, e com um cheiro corporal forte, quando se morava nas ruas e praças e o banho era raro. Enfim, os pedestres mobilizavam todos esses signos enquanto (re) produziam na minha frente, de um lado, atividades econômicas que o senso comum no Brasil costuma associar moralmente a "precariedade" e "informalidade": a venda ou troca ambulante de mercadorias usadas, a pregação religiosa e a prestação de serviços pouco valorizados socialmente, como a sustentação corporal de placas de propaganda ou o conserto de saltos de sapato na rua; de outro lado, atividades socialmente popularizadas como "marginais" e não raro ilícitas, como o jogo, o tráfico de drogas, o roubo e a mendicância.

Em face disso, é sedutor o rótulo "pobreza" - com todas as dificuldades inclusive ideológicas implícitas no termo. E desigualdade social...

Mas em relação a quem? A possibilidade histórica de pobreza na Praça da Sé é indissociável da existência empírica contrapontística de tipos humanos que não padecem das privações acima. Afinal, o sentido de classificações morais como pobreza, precariedade, informalidade, marginalidade, ilicitude se nutre 
da coexistência simbólica dos contrapontos riqueza, estabilidade, formalidade, centralidade, licitude. Ora, nesse contexto semântico o próprio ato de transitar já induz à percepção de uma assimetria de posicionamento social: os transeuntes estão dispensados de permanecer na praça se, em última instância, não lhes aprouver. Pois é esse estado de coisas que meu caderno de campo registra, por referência a pedestres de passagem com quem conversei informalmente em busca das razões que os levavam a atravessar a Praça da Sé com mais ou menos pressa ou, se muito, passar de alguns minutos a meia hora ali para assistir a alguma pregação, encomendar o polimento dos sapatos ou visitar algum engraxate, sapateiro ou músico de rua amigo. Enfim, a constatação se aplica inclusive ao leitor, convidado a imaginar-se nessa praça-sede de catedral brasileira...

Convém, entretanto, não se iludir com a pertinência empírica da associação entre trânsito e assimetria social em relação a quem está fadado a não transitar. É impossível inferir que os transeuntes pertencem de modo cabal a grupos de elite ou de classe média. É verdade que deparar com ternos de linho e sapatos envernizados cruzando a praça aparentemente saídos do Tribunal de Justiça, logo ao lado, reforçava em mim a impressão de advogados ou juristas, portanto de profissões que se consolidaram em São Paulo na esteira do processo de emergência histórica das classes médias, no século XIX (Frehse, 20I I: I65). Mas a plêiade de transeuntes evidentemente não se restringia a tais tipos. Ademais, sua condição fenomênica vem pari passu com padrões de interação social cujas marcas são a impessoalidade e o anonimato (Frehse, 20 I I: 42s), que dificultam significativamente a identificação do perfil social em questão.

De todo modo, o mero enfoque sobre os comportamentos corporais já sinaliza que a coexistência de transeuntes e não-transeuntes na Praça da Sé em 2013 oculta idiomas corporais reveladores de disparidades de posicionamento no espaço social paulistano. Estas desigualdades se (re)produzem justamente pela mediação dos padrões de uso corporal do logradouro por transeuntes e não-transeuntes, e fazem da assimetria comportamental-corporal uma forma socioespacialmente específica de desigualdade social. Basta concentrar-se analiticamente nas regularidades implícitas em suas respectivas técnicas corporais, interações sociais e imaginário sobre a praça e seus habitués.

Quanto aos transeuntes, reapareceram na Praça da Sé de 2013 duas regras relativas a técnicas corporais e à interação social que costumam caracterizar a presença de passantes nos espaços públicos urbanos do mundo ocidental engolfado pela modernidade oitocentista: a passagem física regular por ali, no plano do comportamento corporal, e a impessoalidade, no plano das interações sociais (Frehse, 20I I: 43). Tais padrões fazem par com um imaginário sobre a Praça da Sé e seus usuários habituais que, pelo que notei nas conversas informais com os transeuntes, associa o logradouro a um espaço de mera circulação, evidenciando um misto de desprezo e lamento por tanta gente passar o dia (quando não também a noite) ali “à toa”... 
Já expressões espaciais indicativas da desigualdade comportamental-corporal que caracteriza, por sua vez, os não-transeuntes do logradouro em 2013 são padrões mais diversificados notadamente de técnicas corporais e de interação social. Às vezes se permanecia por horas sentado, como aposentado, engraxate ou sapateiro, em cadeiras ou banquinhos em torno de cadeiras de engraxate, "batendo papo" com terceiros, "visitantes" ou pesquisadoras como eu, durante ou à espera de algum polimento ou conserto de sapatos (4/o2, 25/02). ${ }^{13}$ Em particular sapateiros ou engraxates também informavam, então, os transeuntes de passagem acerca das rotas de ônibus e nomes de ruas do entorno (4/02, 25/02, I2/04, 22/04, I7/05), liam a Bíblia ou observavam, compenetrados, a movimentação local (4/02, 25/02, I7/06, 28/06).

Quando, por sua vez, se era vendedor ambulante, comerciavam-se mercadorias clandestinas em grandes sacolas de plástico ou carrinhos de supermercado cheios de roupas e sapatos usados, cremes, lanternas e/ou celulares, comprados e vendidos sobretudo a quem morava na rua. Já este último tipo de pedestre passava os dias na praça compartilhando sonhos, mágoas, bebida, drogas ou justamente mercadorias angariadas via caridade, esmola ou roubo (25/03, 26/04, passim).

Dentre os músicos de rua a desigualdade comportamental-corporal se expressava espacialmente, de um lado, na permanência física delongada, a voz cansada e rouca, no tablado sombreado da praça diante de um público constituído por poucos transeuntes e muitos não-transeuntes, que acompanhavam a música cantando, quando não também dançando, às vezes ao embalo da cachaça. De outro lado, a assimetria se exprimia através de muito "bate-papo" com os próprios pares, músicos ali e em outras ruas do centro, e conversa com a pesquisadora, nos intervalos das apresentações $(26 / 04,5 / 08) \ldots$

Enfim, todas essas regularidades relativas a técnicas corporais e interações sociais se embaralhavam de modo sui generis nos pregadores pentecostais e membros das chamadas rodas de conversa de religião. A rouquidão da voz que esbravejava "a palavra de Jesus" emanava tanto do corpo que passava horas de pé ao relento, no ritmo do rodízio que assegurava a cada "pastor" duas horas de "oração" em um dos quadrados de fita adesiva esboçados no chão, audiência sobretudo masculina em volta, quanto do corpo dos integrantes masculinos das rodas que vociferavam contra as leituras supostamente equivocadas da Bíblia pelos pregadores ao lado (18/03, I3/05, 28/06, passim).

Derivadas de como esses não-transeuntes variados se serviam do corpo e interagiam enquanto entre eles prevalecia o comportamento corporal da não-circulação em meio ao trânsito, essas regras de conduta potencializam o leque de usos da Praça da Sé. Mas também sugerem que esses pedestres se situam socialmente "abaixo" dos transeuntes, embora a condição social de todos, quanto aos chamados diferenciais de acesso, seja afim. É no plano fenomênico das técnicas corporais e das interações sociais, que está implícito 
nos comportamentos corporais em espaços públicos como a praça-sede da catedral paulistana, que tais assimetrias se (re)produzem e colaboram para a (re)produção da desigualdade social em São Paulo.

Quanto às razões para essa configuração de corpos no espaço, as atividades sociais realizadas dia a dia pelos não-transeuntes no logradouro são indissociáveis das variáveis econômicas e políticas ressaltadas pela bibliografia anteriormente referenciada. Mesmo os estudos sobre os usos dos espaços públicos centrais nas cidades brasileiras destacam a relevância analítica de um ou mais desses aspectos.

A dificuldade é que tais indicadores não explanam as desigualdades corporal-comportamentais. Ajudam a compreender o porquê da presença de tanta gente que não transita pela praça dia a dia, em meio à quantidade de transeuntes e às vigorosas pressões político-administrativas e mesmo urbanísticas em prol do comportamento corporal do trânsito (os setores do logradouro que etnografei não contam com nenhum único banco de praça). Mas não fica claro por que há quem use corporalmente a praça como o faz, espalhando corpo e comida, cadeiras e sacolas pelo espaço enquanto outros apenas passam, impessoais, por ali.

É aqui que destaco analiticamente processos históricos, em particular a densidade histórica desses padrões de uso corporal da Praça da Sé - suas datas históricas, como propôs Lefebvre no método regressivo-progressivo, que permite identificar e explanar o papel mediador da historicidade no espaço produzido pela mediação dos usos cotidianos de espaços empiricamente dados (Frehse, 20I4). Resultados de outra investigação (Frehse, 20I I) permitem sintetizar que a regra da passagem regular e impessoal pelo logradouro é padrão de comportamento corporal que passou a ser socialmente valorizado, como signo de civilidade, nas ruas e praças do centro de São Paulo em especial nas décadas finais do século XIX, quando a cidade virou palco de intensas transformações socioeconômicas, demográficas, políticas, urbanísticas e culturais relativas à realidade social e cultural tão frequentemente sintetizada nas ciências sociais como modernidade, em meio à crise final da escravidão africana no Brasil. Já a regra da permanência física regular ali é mais antiga, passível de ser rastreada no mínimo na primeira metade do século XIX.

Mas e os padrões referentes em especial às técnicas corporais dos não-transeuntes da Praça da Sé em 2013? De fato, eles dependem de objetos materiais e de modos de agir e de pensar ali, cuja data histórica parece ser bem mais recente: por exemplo, os jornais paulistanos noticiam a presença de pregadores na Sé no mínimo desde a década de I980 (Não assinado, I986). Entretanto, também a possibilidade histórica de tais regularidades reside no passado ainda colonial: são variações contemporâneas do vigor da regra da permanência física regular em espaços do mais amplo acesso possível a informações e gentes. 
Por tudo isso, o argumento é de que a desigualdade comportamental-corporal em questão integra uma história social já secular de padrões de conduta em praças centrais como Sé. O deixar-se ficar e a circulação impessoal coexistem ali sobretudo desde o fim da escravidão africana - quando vias e logradouros se tornaram legalmente acessíveis a todo e qualquer pedestre em qualquer hora do dia e da noite, o que, durante os idos escravistas, fora interditado a cativos (Frehse, 20II: 53I-67). A contundência de tal coexistência no logradouro em 2013 sugere que a historicidade de ambas as regras parece ser bem mais lenta do que aquela das transformações urbanísticas, socioeconômicas e mesmo das mudanças nos perfis sociais e culturais dos pedestres da praça nas últimas décadas.

Se essa forma de desigualdade sinaliza para uma clivagem social entre transeuntes e não-transeuntes na Praça da Sé, uma segunda indica que, mesmo entre os aparentemente iguais na pobreza, há assimetrias. São disparidades morais, relativas ao posicionamento diversificado de alguns não-transeuntes no espaço social paulistano pelo fato de uns serem associados por outros a representações socialmente mais ou menos valorizadas como éticas, estéticas - como guias de ação (Lefebvre, I980: 8I). Representações remetem a "presenças do ausente" (Lefebvre, I980: 53), símbolos que nascem no imaginário e por meio dos quais grupos se representam para si e para os outros. Tendo-se em conta que é por se ligarem a valores que as representações guiam a ação, Lefebvre encontra mais uma vez Goffman (I967: 48), para quem uma regra de conduta é "guia para a ação, recomendada não por ser agradável, barata ou efetiva, mas por ser adequada ou justa".

De fato, a possibilidade de apreensão empírica de desigualdades morais na Praça da Sé depende de se atentar para a lógica classificatória que permeia o imaginário dos não-transeuntes sobre o logradouro e os pedestres habituais ali, considerando que imagens estão dentre as formas que assumem as representações (Lefebvre, I980: 240). Notadamente uma representação valorativa se insinuou a mim verbalmente, durante conversas e comentários na minha frente em meio aos usos ocupacionais e de sociabilidade do espaço anteriormente evocados: a Praça da Sé como lugar de atividades sociais e tipos humanos moralmente condenáveis. Foram reveladoras nesse sentido, de um lado, imagens definidas do logradouro, do ponto de vista da presença humana ali; de outro, imagens efêmeras de não-transeuntes precisamente acerca de seus pares situados respectivamente a pouca distância física dali.

Um dos sapateiros do setor triangular foi ferino, quando o conheci: "aqui é o crime, aqui é a Praça da Sé. [...] Ninguém dá nada pra ninguém aqui não; é tudo a mesma malandragem. [...] Na Sé ninguém é amigo, não" (4/02). Ao que um autodenominado camelô acrescentou: No passado a praça "era considerada cartão postal de São Paulo", mas depois "encheu de mendigo, dormindo na praça [...]. Antes não tinha maloqueiro, mendigo dormindo" (4/o2). 
Para um engraxate, no dia em que se dispôs a conversar comigo, o "único problema" da Praça da Sé seria "esse pessoal largado aí, morador de rua" (7/06). Um pregador, enfim, foi mais vago, mas a conotação moralmente negativa reapareceu: a Sé seria uma "selva de pedra" onde ele nunca teria tido "problema com ninguém" (28/06).

Os comentários sugerem uma valoração moralmente negativa não apenas de atividades há muito socialmente marginalizadas no espaço social paulistano - a mendicância, o morar na rua, a "malandragem" (Stoffels, 1977) -, mas de seus supostos protagonistas. Não é a condição social pobre de mendigos e moradores de rua o problema, mas atributos comportamentais supostamente indevidos implícitos na mendicância e no morar na rua.

Trata-se de imagens do espaço marcadamente valorativas, impregnadas de concepções morais sobre o quê e, sobretudo, quem seria certo ou errado, bom ou ruim ali. É como se o logradouro contivesse "em si" pedestres caracterizados por traços morais valorativamente negativos, por referência ao espaço social paulistano: a aptidão para o crime, para o não-trabalho implícito nas noções de maloqueiro, mendigo. ${ }^{\mathrm{I4}}$ Se quem passa os dias na praça é pobre, portanto socialmente inferior, nem todos são moralmente baixos.

Quanto às imagens sobre os pedestres habituais do espaço, foram constantes as observações moralmente ácidas que os não-transeuntes faziam uns dos outros na minha frente, em meio ao e apesar do muito que os unia social e fenomenicamente no logradouro, dia a dia. Às vezes a crítica se insinuava no plano religioso, como a de um engraxate aos participantes das rodas de conversa de religião (seriam "fariseus" descrentes de Jesus - 4/02) e a uma moça que, aparentemente bêbada, certo dia polemizou com um pregador em ação (é "mal da cabeça" - 25/o2). Já para um pregador, seriam os "fariseus" os doentes mentais (13/05), enquanto, por sua vez, para um dos debatedores de religião era um pedinte aleijado esparramado pelo chão com sua muleta que "tem verme, não acredita na Bíblia" (8/02). Em todos esses casos, diferenças religiosas aparecem associadas a atributos morais com clara conotação negativa. O resultado representacional é a explícita desigualdade moral entre quem segue e não seguiria os preceitos religiosos nos quais os autores de tais comentários creem.

Um segundo pomo simbólico de discórdia moral era o comportamento feminino. Ou melhor: associações simbólicas entre determinado idioma corporal feminino e certas práticas de sexo. Como já demonstrei (Frehse, 20I3c: I22), provêm de mulheres os comentários mais mordazes sobre, por exemplo, ser "mulher sem vergonha, vagabunda, [...] perdida" a moça que, sob aparente efeito de drogas e trajando shorts e camiseta, esbravejou contra o pregador (25/o2); ou o fato de que uma moradora de rua "dorme toda noite com um cara diferente", sendo "mulher da vida, vadia": "nem" o seu "marido" então atual, também morador de rua, "quer saber dela" (7/06). Cabe, entretanto, sa- 
lientar que homens também contribuíam para o repertório da depreciação moral feminina. Um dos sapateiros do setor triangular da praça comentou comigo acerca de uma vendedora de cigarros de aparência física "masculinizada": ela seria "um sapatão; quando você conversar com ela, vai levar uma cantada" (I 2/04).

Uma terceira pecha associada por não-transeuntes a seus pares era a de "gente que rouba". Comentou comigo uma moradora de rua de mais de cinquenta anos sobre uma jovem moradora de rua que, grávida de 22 anos, se encontrava a poucos metros dali: "ela tá roubando muito" (5/04). Nesse mesmo dia, mais uma moradora de rua esbravejou contra os roubos na praça, mas a autora seria outra: justamente outra mulher que, como ela, integrava uma "maloca" (grupo espacialmente enraizado) ali e, "zuretada", teria levado a sua mochila.

E assim chego a um quarto critério simbólico a subsidiar a depreciação moral de uns por outros: um estado mental supostamente doentio, ligado ou não à drogadição (inclusive de bebidas). É uma variável classificatória sobre a qual também já discorri alhures (Frehse, 20I3C: I 2I). Aqui, saliento apenas que se trata de poderoso parâmetro simbólico a desigualar moralmente mesmo os mais iguais, como as duas moradoras de rua referenciadas anteriormente, mas também dois engraxates: o primeiro comentou comigo que a cadeira de engraxar do segundo seria "prateada" porque este "não bateria bem da cabeça" (27/05).

À luz dessas vertentes classificatórias da desigualdade moral, espero ter demonstrado que estamos em face de mais uma forma de desigualdade cuja forma de expressão espacial primordial é o idioma corporal dos não-transeuntes. São os signos relativos à aparência física e a atos pessoais diversos que medeiam a avaliação moral negativa de uns por outros. E crucial é: moralmente condenável é sempre o outro.

Esta lógica classificatória evidencia uma forma de assimetria alheia aos processos econômicos e políticos, aos atores e instituições presentes na bibliografia anteriormente revisada. O que não surpreende, considerando-se que os estudos se pautam nas desigualdades entre pobres e ricos no espaço urbano, passando ao largo daquelas passíveis de se reproduzirem entre os pobres pela mediação do espaço.

Como explicar tal desigualdade moral? Também nela reconheço heranças de uma regra de interação social de longa duração nas ruas e praças centrais de São Paulo. Refiro-me àquilo que, em outro momento (Frehse 20I I: 254), chamei de pessoalidade, vinculação simbólica que o pedestre, pela mediação de seu idioma corporal na rua, nutre voluntária ou involuntariamente com o todo social em que se situa. Mas, ao mesmo tempo, tudo é diferente do passado. É que numa praça multitudinária como a Praça da Sé de 2013 , onde poucos não-transeuntes se conheciam pessoalmente, a única vinculação simbólica possível diz respeito aos atributos morais do pedestre que o idioma corporal pode 
revelar. Daí que falo em pessoalidade moral, padrão de interação social que afasta o logradouro das ruas e praças que o contato com a bibliografia sobre a rua no Brasil deixou entrever (Frehse, 2013c: I23).

E assim há como, enfim, deixar para trás os corpos dos pedestres da praça-sede da catedral paulistana. Os corpos e a praça se revelam espaços prenhes de uma dinâmica normativa de natureza simbólica que dota o espaço do debate sobre a desigualdade social no Brasil urbano do presente de globalização econômica de contornos metodológicos e teóricos pouco usuais que há, enfim, como evidenciar de maneira sintética.

\section{INTERLOCUÇÕES OUTRAS}

Produto de uma atenção investigativa explícita a espaços diversos - dos empiricamente observados aos teoricamente construídos e vice-versa, mas sempre passando pelos etnograficamente percebidos e vividos -, este estudo acaba por ir ao encontro de um espaço outro, ainda. Penso num campo de discussões que apenas desde o início do século XXI, e a partir de solo alemão, tem merecido atenção sistemática do pensamento sociológico (Frehse, 2013d: ro): o debate em torno da dimensão espacial das práticas sociais. Como será que materializações físicas e/ou de representações simbólicas de relações simultâneas entre bens materiais e/ou imateriais interferem (ou não) em modos de agir, sentir e pensar socialmente? As sínteses simbólicas mais acabadas de tais conjuntos de vínculos pautados na concomitância são justamente categorias linguísticas relativas a "espaço", com acepções etimológicas e semânticas que variam com o respectivo contexto sociocultural e histórico.

Em meio a tantos espaços, assumi uma perspectiva sui generis acerca das relações dos pedestres em particular com espaços públicos como a Praça da Sé paulistana "comercial e útil" de 2013 pela mediação dos padrões de uso de seus próprios corpos (outros espaços) ali e então através do idioma (justamente corporal) pelo qual se comunicam socialmente, vieram à tona duas formas de desigualdade social que estão virtualmente ausentes do debate sobre o tema, quando o assunto são cidades brasileiras dos últimos 25 anos. Se fugiria aos limites deste texto aprofundar-se nas razões para este estado da arte, a análise sugere dois aspectos que gostaria, aqui, ao menos de tangenciar.

Refiro-me, em primeiro lugar, à importância metodológica que no debate assumem, mesmo que de modo tácito, teorias de estratificação social, abordagens que privilegiam diferenças e diferenciações entre grupos sociais distintos - "classes", "camadas". Mesmo que indiretamente, é o campo dos estudos sobre esse tema sociológico que acaba por ser mobilizado toda vez que a pergunta da desigualdade social é enfrentada analiticamente com o olhar teórico atento às disparidades entre ricos e pobres, elites e classes populares etc. Nada disso é problema quando a realidade empírica pesquisada 
"pede" esse tipo de tratamento e interpretação. Mas e quando não é explícita nesse sentido, como é o caso dos padrões de uso corporal, pelos pedestres, de um espaço público como a Praça da Sé paulistana em 20I3?

Ligado a esse aspecto, há um segundo, a ser considerado quando se reflete sobre os porquês do enfoque investigativo costumeiro das ciências sociais em desigualdades entre grupos sociais nas cidades brasileiras. Trata-se justamente do objeto investigativo priorizado a cada vez, por referência à dimensão social do espaço. O intuito de contribuir para o debate sobre problemas como segregação e estrutura socioespacial, por exemplo, conduz o pesquisador instantaneamente a preocupar-se com padrões de habitação nas cidades. Ora, habitar pressupõe fixação espacial, um uso específico do espaço que, embora fundamental e eivado de formas e causas de desigualdade social decisivas, não é de forma alguma o único que vige em nossas urbes.

Marcada pela ênfase epistemológica nas regras de uso que os pedestres fazem de seus próprios corpos em espaços públicos centrais como a praça-sede da catedral metropolitana paulistana, parece-me que a interpretação aqui desenvolvida acaba por se inserir em um espaço cognitivo ainda pouco explorado pelos estudos dos vínculos entre desigualdade social e espaço urbano no Brasil atual. É a seara da dimensão simbólica das desigualdades: como processos sociais de atribuição de significados pela mediação de classificações, noções de natureza representacional, contribuem para a (re)produção de assimetrias de posicionamento social, na atualidade. Na verdade, mesmo nos estudos urbanos internacionais essa preocupação tem sido mais associada à problemática da diferença do que àquela da desigualdade (Harding \& Blokland, 20I4: I7I-2 I8).

Com efeito, o assunto vem sendo trabalhado sobretudo por teóricos sociais que associam desigualdade, cultura e história, ao refletir sobre os atuais tempos de globalização. ${ }^{15}$ Se esse leque de abordagens abre todo um espaço de aproximação com quem, como eu, se preocupa com a mecânica simbolicamente fugaz e historicamente profunda que permeia a (re)produção da desigualdade social no Brasil na seara da vida cotidiana, o fato é que, ao mesmo tempo, uma diferença-distância significativa se impõe. É que falta espaço...

Não me refiro àquele de natureza relacional que, embutido na noção de figuração de Norbert Elias, tem sido utilizado para apreender as desigualdades interdependentes que se (re)produzem na América Latina para além das fronteiras nacionais (Costa, 20I I; Braig et al., 20I3: I I). Penso no espaço urbano da região e, em particular, do Brasil e, ali, em espaços públicos e corporais como os que aqui importaram. Tudo isso ao mesmo tempo, pela mediação do corpo humano, que é espaço do espaço público do espaço urbano. E, por tudo isso, no mesmo espaço pela mediação do tempo, evidenciando a seu modo que o tempo se distingue, mas não se separa do espaço. 
Fraya Frehse é professora do Departamento de Sociologia da Universidade de São Paulo, onde fez mestrado e doutorado em Antropologia Social; e realizou pós-doutoramento nas Universidades Livre e Humboldt de Berlim. Pesquisa sobre vida cotidiana e história; espaço como objeto sociológico; mobilidade urbana; cidade, metrópole e modernidade no Brasil; espaços públicos urbanos (em especial ruas e praças); imagem (em especial fotografia de rua) no Brasil; cidade de São Paulo (história). É autora de Ô da Rua! $O$ transeunte e o advento da modernidade em São Paulo (20I I). 


\section{NOTAS}

I Artigo elaborado no âmbito de um fellowship no Research Network on Interdependent Inequalities in Latin America da Freie Universität Berlin, entre fevereiro e abril de 2014. Todas as fotografias foram feitas por mim (๔ Fraya Frehse).

2 Referenciarei sobretudo publicações acessadas via levantamento no Ibero-Amerikanisches Institut e na Freie Universität Berlin entre abril e julho de 20I4, com base em combinações em inglês, espanhol e português dos termos cidade, espaço urbano, América Latina e Brasil com desigualdade (social), pobreza, segregação, marginalidade (social/urbana), vulnerabilidade social, vida cotidiana. Agradeço aos professores Sérgio Costa e Martina Sproll, e aos estudantes-assistentes Florian Lutz e Fabio Santos pelo apoio institucional e logístico que viabilizou a investigação.

3 Ver, entre outros, Kowarick (I 979, 2000, 2009, 20 I I), Martins (I997, 2002, 2008a, 20I I), Ribeiro (2000a, 200I/2002), Ribeiro \& Santos Jr. (2007), Caldeira (I997, 2000), Torres et al. (2004), Marques \& Torres (2005), Marques (2010, 2014, 20I5).

4 Conduzido a partir de fevereiro de 2013, o trabalho de campo consistiu em observação participante pautada sobretudo em observação direta e conversas informais com os não-transeuntes do logradouro acerca de suas concepções sobre aquele espaço, usuários e usos deste. Para detalhes sobre a localização mais recorrente dos tipos de não-transeuntes no logradouro e a dinâmica de interação social durante a etnografia, ver, respectivamente, croqui e esclarecimentos em Frehse (2013C: 106-II3).

5 Ver, entre outros, Caldeira (2000: I2), Torres et al. (2004: I), Marques \& Torres (2005: passim), Martins (20 I I: I3), Villaça (20I I: 37).

6 Entretanto, foi sobretudo pela pena de terceiros em contato com as publicações do autor desde o fim dos anos I960, que o problema frutificou em estudos de influência significativa na discussão aqui em foco. Penso no Manuel Castells (2000) que conviveu com Lefebvre em Nanterre nos anos I960, e cuja "questão urbana" impactou de modo decisivo na abordagem pioneira de Lúcio Kowarick (I979) acerca da "espoliação urbana" na São Paulo dos anos I970. Ademais, relembro Edward Soja (I989), um dos raros a 
atribuir o seu "spatial turn" a Lefebvre, e cuja abordagem transparece na explanação precursora de Teresa Caldeira (2000) sobre a questão de interesse aqui.

7 Ver, para uma exceção, Marques (2005: 37)

8 Por referência às políticas públicas, o autor associa as disparidades de acesso à "vulnerabilidade de ativos" de Caroline Moser (I998) e, no caso do mercado de trabalho, à "estrutura de oportunidades" de Kaztman (I999). Ver, para uma síntese do debate, Marques (2005: 4I-43).

9 Ver, entre outros, Martins (I997, 200I, 2002, 2008a, 20I I), Villaça (I998, 20I I), Kowarick (2000, 2009), Ribeiro (2000a, 2002), Caldeira (2000), Ribeiro \& Lago (200I), Telles (200I), Carvalho (200I), Lago (200I/2002), Sposati et al. (2004), Torres et al. (2004), Marques \& Torres (2005a), Raichelis (2006), Ribeiro (2006), Garcia (2006), Ribeiro \& Santos Jr. (2007), Marques (2010, 2014, 20I5).

ıo Ver Martins (I997: I8) e, na chave interpretativa dos diferenciais de acesso, Marques (2005: 47).

I I Convém lembrar que, nos anos 1950 e I960, se discutia bastante em termos de cultura da pobreza; entre as décadas de I960 e I970, de marginalidade social; a partir dos anos I980, sobretudo com base em exclusão social e, a partir dos anos 2000, também em vulnerabilidade social - categorias cujo conteúdo ideológico nem sempre é estranhado. Para revisões bibliográficas sobre periferias e segregação, ver, entre outros, Espaço \& Debates (2004), Marques (2005: 2 I-44), Bógus (2009); sobre favelas, ver Valladares (2005); sobre gentrificação, Rubino (2009). Para críticas do conteúdo ideológico de marginalidade social, ver Paoli (I974), Kowarick (I975) e Foracchi (I982); de exclusão, Martins (1997: 25-38; 2002: 25-47).

I 2 Assim, a bibliografia vai ao encontro de uma tendência epistemológica comum nos estudos urbanos internacionais atuais: assumir os usos de espaços públicos urbanos como "expressões espaciais de diferenciação", ou seja, do estabelecimento de limites intergrupais por critérios de gênero, de raça/etnicidade, de idade, sexualidade e classe social (Harding \& Blokland 20I4: I85-2I4).

I3 Os números entre parênteses indicam dia e mês da situação respectivamente etnografada. 
I4 Sobre a noção de maloqueiro nesse contexto, ver Frehse (20I3C: I I9).

I5 Penso em autores que pesquisam empiricamente, por exemplo, as interconexões históricas e transnacionais de classificações sociais como classe, raça e etnia, na região (Costa, 20II); estruturas sociais pré-capitalistas e o discurso científico sobre o capitalismo (Rehbein \& Souza, 20I4); enfim, a própria natureza da cultura (Reygadas, 20I5). Isso embora haja também quem, na chave goffmaniana, enfoque os processos sócio-históricos embutidos na dimensão interacional das desigualdades, evidenciando como percepções cotidianas de assimetrias entre indivíduos e entre indivíduos e instituições, na América Latina, se expressam no plano da interação social (Araujo, 20I3).

\section{REFERÊNCIAS BIBLIOGRÁFICAS}

Araujo, Kathya. (2013). Interactive inequalities and equality in the social bond. DesiguALdades.net Working Paper Series, 54, Berlim, mimeo.

Bógus, Lúcia M. M. (2009). Segregações urbanas. In: Fortuna, Carlos \& Leite, Rogerio P. (orgs.). Plural de cidade. Coimbra: CES/Almedina, p. I I5-I 26.

Braig, Marianne et al. (2013). Soziale Ungleichheiten und globale Interdependenzen in Lateinamerika. DesiguALdades.net Working Paper Series, 4, Berlim, mimeo.

Caldeira, Teresa Pires do Rio. (2000). Cidade de muros. São Paulo: Edusp.

Caldeira, Teresa Pires do Rio. (I 997). Enclaves fortificados: a nova segregação urbana. Novos Estudos, 47, p. I55-76.

Carvalho, Inaiá Maria Moreira de et al. (200I). Dinâmica metropolitana e estrutura social em Salvador. Tempo Social, I 3/2, p. 89-I I 4 .

Castells, Manuel. (2000). A questão urbana. Trad. Arlene Caetano. Rio de Janeiro: Paz e Terra.

Costa, Sérgio. (20 I I). Researching entangled inequalities in Latin America. DesiguALdades.net Working Paper Series, 9, Berlim, mimeo. 
Engels, Friedrich. (1972). Die Lage der arbeitenden Klasse in England. In: Karl Marx - Friedrich Engels-Werke. Berlim: Dietz Verlag, p. 225-506 (vol. 2).

Espaço \& Debates. (2004). Espaço \& Debates, 24/45, p. I-I36. Foracchi, Marialice M. (I982). A participação social dos excluídos. São Paulo: Hucitec.

Frangella, Simone M. (2009). Corpos urbanos errantes. São Paulo: Annablume/Fapesp.

Frehse, Fraya. (20I4). For difference "in and through" São Paulo: the regressive-progressive method. In: Stanek, Lukasz et al. (orgs.). Urban revolution now. Surrey: Ashgate, p. 243-62.

Frehse, Fraya (2013a). Os tempos (diferentes) do uso das praças da Sé em Lisboa e em São Paulo. In: Fortuna, Carlos \& Leite, Rogerio P. (orgs.). Diálogos urbanos. Coimbra: Almedina, p. I 27-73.

Frehse, Fraya (2013b). Zeiten im Körper: Das Potenzial der Lefebvre'schen Methode für die (lateinamerikanische) Stadtforschung. In: Huffschmid, Anne \& Wildner, Kathrin (orgs.). Stadtforschung aus Lateinamerika. Bielefeld: Transcript, p. 145-69.

Frehse, Fraya. (2013C). A rua no Brasil em questão (etnográfica). Anuário Antropológico/20 I 2, 38/2, p. 99- 29.

Frehse, Fraya. (2013d). Apresentação [ao dossiê "As Ciências Sociais e o Espaço"]. Tempo Social, 25/2, p. 9-ı6.

Frehse, Fraya. (20I I). Ô da rua! São Paulo: Edusp.

Frehse, Fraya. (2009). Usos da rua. In: Fortuna, Carlos \& Leite, Rogerio P. (orgs.). Plural de cidade. Coimbra: CES/Almedina, p. I5I-70.

Garcia, Antonia dos Santos. (2006). Desigualdades raciais e segregação urbana em antigas capitais: Salvador, Cidade d'Oxum e Rio de Janeiro, Cidade de Ogum. Tese de Doutorado. PPGSA/ Universidade Federal do Rio de Janeiro.

Goffman, Erving. (1983). Behavior in public places. Nova York/ Londres: The Free Press/ Collier-Macmillan Limited.

Goffman, Erving. (1967). Interaction ritual. Garden City: Anchor Books.

Harding, Alan \& Blokland, Talja. (20I4). Urban theory. Los Angeles/Londres/Nova Déli/Cingapura/Washington, DC: Sage. 
Kaztman, Rubén. (I999). Activos y estruturas de oportunidades. Montevidéu: PNUD-CEPAL.

Kowarick, Lúcio. (20 I I). O centro e seus cortiços: dinâmicas socioeconômicas, pobreza e política. In: Kowarick, Lúcio \& Marques, Eduardo (orgs.). São Paulo: Novos percursos e atores. São Paulo: Ed. 34, p. 79-103.

Kowarick, Lúcio. (2009). Viver em risco. São Paulo: Ed. 34. Kowarick, Lúcio. (2000). Escritos urbanos. São Paulo: Ed. 34. Kowarick, Lúcio. (I979). A espoliação urbana. Rio de Janeiro: Paz e Terra.

Kowarick, Lúcio. (1975). Capitalismo e marginalidade na América Latina. Rio de Janeiro: Paz e Terra.

Lago, Luciana Corrêa do. (200I/2002). A lógica segregadora na metrópole brasileira: novas teses sobre antigos processos. Cadernos IPPUR, I5-I6/2-I, p. I55-76.

Lefebvre, Henri. (2009). Le droit à la ville. 2a. ed. Paris: Anthropos.

Lefebvre, Henri (200 Ia). Du rural à l'urbain. Paris: Anthropos. Lefebvre, Henri. (200Ib). Préface. In: Raymond, Henri et al. (orgs.). L'habitat pavillonnaire. 2a. ed. Paris: L'Harmattan, p. 7-23.

Lefebvre, Henri. (2000). La production de l'espace. 3a. ed. Paris: Anthropos.

Lefebvre, Henri. (1992). Eléments de rythmanalyse. Paris: Syllepse.

Lefebvre, Henri. (I980). La présence et l'absence. Paris: Casterman.

Lefebvre, Henri. (1958). Critique de la vie quotidienne. 2a. ed. Paris: L’Arche Éd. (vol. I).

Marques, Eduardo (org.). (20I5). A metrópole de São Paulo no século XXI. São Paulo: Ed. Unesp/CEM.

Marques, Eduardo. (20I4). Estrutura social e segregação em São Paulo: Transformações na década de 2000. DADOS Revista de Ciências Sociais, 57/3, p. 675-7io.

Marques, Eduardo. (20I0). Redes sociais, segregação e pobreza. São Paulo: Ed. Unesp.

Marques, Eduardo. (2005). Elementos conceituais da segregação, da pobreza urbana e da ação do Estado. In: Marques, 
Eduardo \& Torres, Haroldo (orgs.). São Paulo: Segregação, pobreza e desigualdade social. São Paulo: Senac, p. I9-56.

Marques, Eduardo \& Torres, Haroldo (orgs.) (2005a). São Paulo: Segregação, pobreza e desigualdade social. São Paulo: Senac, Martins, José de Souza. (20I I). A política do Brasil lúmpen e místico. São Paulo: Contexto.

Martins, José de Souza. (2008a). A sociabilidade do homem simples. 2a. ed. São Paulo: Contexto.

Martins, José de Souza. (2008b). A economia oculta da favela. O São Paulo, 53/2692, p. A2.

Martins, José de Souza. (2002). A sociedade vista do abismo. Petrópolis: Vozes.

Martins, José de Souza. (200I). Depoimento. Espaço \& Debates, 42, p. 75-84.

Martins, José de Souza. (I997). Exclusão social e a nova desigualdade. São Paulo: Paulus.

Milanesi, Renata. (2002). Evolução urbana e espaço público. Dissertação de Mestrado. FFLCH/Universidade de São Paulo.

Moser, Caroline. (1998). The asset vulnerability framework: reassessing urban poverty reduction strategies. World Development, 26/I, p. I- I9.

Não assinado. (I986). Na Sé, torcedores e pregadores. O Estado de S. Paulo, I7 de junho, p. 46.

Paoli, Maria Celia P. M. (1974). Desenvolvimento e marginalidade. São Paulo: Pioneira.

Park, Robert. (1967). The city: suggestions for the investigation of human behavior in the urban environment. In: Park, Robert \& Burgess, Ernest (orgs.). The city. Chicago/Londres: The University of Chicago Press, p. I-46.

Raichelis, Raquel. (2006). Gestão pública e a questão social na grande cidade. Lua Nova, 69, p. 13-48.

Rehbein, Boike \& Souza, Jessé. (20I4). Ungleichheit in kapitalistischen Gesellschaften. Bad Langensalza: Beltz.

Reygadas, Luis. (20I5). The symbolic dimension of inequalities. In: DesiguALdades.net Working Paper Series, 78, Berlim, mimeo.

Ribeiro, Ana Clara Torres. (2006). Presenças recusadas: territórios populares em metrópoles brasileiras. In: Nunes, 
Brasilmar Ferreira (org.). Sociologia de capitais brasileiras. Brasília: Líber Livro Ed., p. I I-33.

Ribeiro, Luiz Cesar de Queiroz. (2001/2002). Segregação, acumulação urbana e poder na metrópole do Rio de Janeiro. Cadernos IPPUR, , I5-I6/2-I, p. 79-I03.

Ribeiro, Luiz César de Queiroz. (2002). A cidade, as classes e a política: uma nova questão urbana brasileira? In: Oliveira, Lúcia Lippi (org.). Cidade: história e desafios. Rio de Janeiro: Ed. FGV, p. 84-I05.

Ribeiro, Luiz Cesar de Queiroz (org.). (2000a). O futuro das metrópoles. Rio de Janeiro: Revan/Fase.

Ribeiro, Luiz Cesar de Queiroz. (200ob). Cidade desigual ou cidade partida? Tendências da metrópole do Rio de Janeiro. In: Ribeiro, Luiz Cesar de Queiroz (org.). O futuro das metrópoles. Rio de Janeiro: Revan/Fase, p. 63-98.

Ribeiro, Luiz Cesar de Queiroz \& Santos Jr., Orlando Alves dos (orgs.). (2007). As metrópoles e a questão social brasileira. Rio de Janeiro: Revan.

Ribeiro, Luiz Cesar de Queiroz \& Santos Jr., Orlando Alves dos. (2003). Democracia e segregação urbana: reflexões sobre a relação entre cidade e cidadania na sociedade brasileira. Revista EURE, 29/88, p. 79-85.

Ribeiro, Luiz Cesar de Queiroz \& Lago, Luciana Corrêa do. (200I). A oposição favela-bairro no espaço social do Rio de Janeiro. São Paulo em Perspectiva, I5/I, p. I44-54.

Rolnik, Raquel. (I999). Territorial exclusion and violence: the case of São Paulo, Brazil. Washington, DC: Woodrow Wilson International Center for Scholars.

Rubino, Silvana. (2009). Enobrecimento urbano. In: Fortuna, Carlos \& Leite, Rogerio Proença (orgs.). Plural de cidade. Coimbra: CES/Almedina, p. 25-40.

Rui, Taniele. (20I5). Nas tramas do crack. São Paulo: Terceiro Nome.

Soja, Edward. (I989). Postmodern geographies. Londres/Nova York: Verso.

Sposati, Alzaíza et al. (2004). A pesquisa sobre segregação: conceitos, métodos e medições. Espaço \& Debates, 24/45, p. 87-109. 
Stoffels, Marie-Ghislaine. (I977). Os mendigos na cidade de São Paulo. Rio de Janeiro: Paz e Terra.

Telles, Vera da S. (200I). Pobreza e cidadania. São Paulo: Ed. 34. Torres, Haroldo et al. (2004). The spatial dimension of urban poverty. Comunicação no Encontro do MacArthur Research Network on Inequality and Economic Performance e do Instituto Futuro Brasil. Rio de Janeiro: IBMEC. Mimeo. Valladares, Lícia do Prado. (2005). A invenção da favela. Rio de Janeiro: Ed. FGV.

Villaça, Flávio. (20I I). São Paulo: segregação urbana e desigualdade. Estudos Avançados, 25/71, p. 37-59.

Villaça, Flávio. (1998). Espaço intra-urbano no Brasil. São Paulo: Studio Nobel/Fapesp/Lincoln Institute. 


\section{DA DESIGUALDADE SOCIAL NOS ESPAÇOS PÚBLICOS CENTRAIS BRASILEIROS}

Resumo

As ciências sociais dedicadas à desigualdade social nas cidades brasileiras ressaltam o papel que a distribuição residencial dos grupos sociais no espaço urbano tem exercido na produção e/ou reprodução das assimetrias de posicionamento social, com a aceleração da globalização econômica desde a década de I990. Mas o que ocorre em espaços receptivos à diversidade social como a Praça da Sé, em São Paulo, nos dias úteis da semana? Submeto dados etnográficos registrados em 39 tardes de segundas e sextas-feiras úteis em 2013 ao prisma metodológico dialético e fenomenológico lefebvriano e goffmaniano. Busco responder como e por que o uso que os pedestres fizeram corporalmente desse logradouro então pode interferir na (re)produção da desigualdade social na São Paulo desta segunda década de século XXI. Virão à tona, assim, seculares desigualdades comportamental-corporais e morais.

\section{ON SOCIAL INEQUALITY IN THE BRAZILIAN CENTRAL PUBLIC SPACES}

Abstract

The social sciences on social inequality in Brazil emphasize the role that the residential of social groups in urban space plays in the production and/or reproduction of asymmetries of social positioning, with the acceleration of economic globalization as of the rg9os. But what happens in urban spaces that, like the Praça da Sé, in the city of São Paulo, are highly open to social diversity during workdays? The ethnographic data based on the observation of 39 Monday and Friday afternoons in 2013 is submitted to a Lefebvrean and Goffmanian dialectical and phenomenological perspective. I aim to answer how and why the bodily use pedestrians made of this place may interfere in the (re) production of social inequality in São Paulo in this second decade of the 2 Ist century. Hence secular body-behavioural and moral inequalities will come to the fore.
Palavras-chave

Desigualdade social (Brasil);

Espaço público urbano;

Corpo;

Uso do espaço;

Cidade (Brasil).

\section{Keywords}

Social inequality (Brazil);

Urban public space;

Body;

Use of space;

City (Brazil). 